characterization of an Erwinia carotovora subsp. carotovora pectin lyase gene that responds to DNA-damaging agents. J. Bacteriol. 172:3284-3289.

McEvoy, J. L., K.K. Thum, and A.K. Chatterjee. 1987. Expression of the E. coli lexA $A^{+}$gene in Erwinia carotovora subsp, carotovora and its effect on production of pectin lyase and carotovoricin. Fed. European Microbiol. Soc. Microbiol. Lett. 42:205-208.

Mount, M.S., P.M. Berman, R.P. Mortlock, and J.P. Hubbard. 1979. Regulation of endopolygalacturonate transeliminase in an adenosine 3',5'-cyclic monophosphate-deficient mutant of Erwinia carotovora. Phytopathology 69:117-120.

Murata, H., J.L. McEvoy, A. Chatterjee, A. Collmer, and A.K. Chatterjee. 1991. Molecular cloning of an aepA gene that activates production of extracellular pectolytic, cellulolytic, and proteolytic enzymes in Erwinia carotovoia subsp, carotovora. Mol. Plant-Microbe Interactions 4:239246.

Pastan, I. and S. Adhya, 1976. Cyclic adenosine 5'-monophosphate in Escherichia coli. Bacteriol. Rev. 40:527-551.

Payne, J. H., C. Schoedel, N.T. Keen, and A, Collmer, 1987. Multiplication and virulence in plant tissues of Escherichia coli clones producing pectate lyase isozymes PLb and PLe at high levels and of an Erwinia chrysanthemi mutant deficient in PLe. Appl. Environ. Microbiol. 53:23 15-2320.

Perombelon, M.C.M. 1987. Pathogenesis by pectolytic Erwinias, p. 109-120. In: E.L. Civerolo, A. Collmer, R.E. Davis, and A.G. Gillaspie (eds.). Plant pathogenic bacteria. Martinus Nijhoff, Dordrecht,

Perombelon, M.C.M. and A. Kelman. 1980. Ecology of the soft rot Erwinias. Annu. Rev. Phytopathol. 18:361-387.

Pirhonen, M., H. Saarilahti, M-B. Karlsson, and E.T. Palva. 1991. Identification of pathogenicity determinants of Erwinia carotovora subsp. carotovora by transposon mutagenesis. Mol. Plan-Microbe Interactions 4:276-283.

Ried, J.L. and A. Collmer, 1988. Construction and Characterization of an Erwinia chrysanthemi mutant with directed deletions in all of the pectate lyase structural genes. Mol. Plant-Microbe Interactions 1:32-38.

Roberts, D. P., P.M. Berman, C. Allen, V.K. Stromberg, G.H. Lacy, and M.S. Mount. 1986. Requirement for two or more Erwinia carotovora subsp. carotovora pectolytic gene products for maceration of potato tuber tissue by Escherichia coli, J. Bacteriol. 167:279-284.

Saarilahti, H. T., P. Heino, R. Pakkanen, N. Kalkkinen, L Palva, and E.T, Palva. 1990. Structural analysis of the pehA gene and characterization of its protein product, endopolygalacturonase, of Erwinia carotovora subspecies carotovora. Mol. Microbiol, 4: 1037-1044.

Tanabe, H. and Y. Kobayashi. 1987, Plant-tissue maceration caused by pectinolytic enzymes from Erwinia spp, under alkaline conditions. Agr. Biol. Chem, 51:2845-2846.

Thum, K. K., F. Barras, Y. Kegoya-Yoshino, and A.K. Chatterjee. 1987. Pectate lyase of Erwinia chrysanthemi: PelE-like polypeptides and pelE homologous sequences in strains isolated from different plants. Physiol. Mol. Plant Pathol. 31:429439.

Tsuyumu, S. 1977. Inducer of pectic acid lyase in Erwinia carotovora. Nature 269:237-238.

Tsuyumu, S. and A.K. Chatterjee, 1984. Pectin lyase production in Erwinia chrysanthemi and other soft-rot Erwinia species. Physiol. Plant Pathol. 24:291-302.

Tsuyumu, S., M, Miura, and S. Nishino. 1991. Distinct induction of pectinases as a factor determining host specificity of soft rot Erwinia,p.3141, In: S.S. Patil, S. Ouchi, D. Mills, and C. Vance (eds.). Moleculm strategies of pathogens and host plants, Springer-Verlag, Berlin.

Ullmann, A. and A. Danchin. 1983. Role of cyclic AMP in bacteria, p. 1-53. In: P. Greengard and G.A. Robison (eds.). Advances in cyclic nucleotide research. vol. 15. Raven Press, New York.

Walker, G.C. 1984. Mutagenesis and inducible responses to deoxyribonucleic acid damage in Escherichia coli. Microbiol. Rev. 48:60-93.

Walker, G.C. 1987. The SOS response of Escherichia coli, p. 13461357. In: F.C. Neidhardt, J.L. Ingraham, K.B. Low, B. Magasanik, M. Schaechter, and H.E. Umbarger (eds.). Escherichia coli and Salmonella typhimurium. vol. 2. Amer. Sot. Microbial., Washington, D.C.

Zink, R. T., J,K. Engwall, J.L. McEvoy, and A.K. Chatterjee. 1985. recA is required in the induction of pectin lyase and carotovoricin in Erwinia carotovora subsp. carotovora. J. Bacteriol. 164:390-396.

\title{
Integrating Biological Control into Postharvest Disease Management Strategies
}

\author{
Rodney G. Roberts ${ }^{1}$ \\ U.S. Department of Agriculture-Agricultural Research Service, Tree Fruit Research Laboratory, \\ Wenatchee, WA 98801
}

Technological advances in regular (cold, ambient atmosphere; RA) and controlled-atmosphere (CA) storage, computerized sorting and grading, and mechanical processing and packing of apple (Malus domestics Borkh.) and other tree fruits allow the industry to harvest, store, and market large crops efficiently. Unfortunately, the same postharvest diseases that occurred 60 years ago still cause economic losses (Baker and Heald, 1932; Heald and Ruehle, 1931), although perhaps not to the same extent. Blue mold (caused by Penicillium expansum Link), gray mold (caused by Botrytis cinerea Pers.:Fries), and mucor rot (caused by Mucor piriformis E. Fisch.) cause economic losses for growers and packers of apples and pears (Pyriscommunis L.) every year. Bull's eye rot of apple and pear\{ caused byCryptosporiopsis malicorticis (Cordl.) Nann. [Pezictla malicorticis (H. Jacks.) Nann.] \} causes episodic losses when environmental conditions at petal fall and harvest are conducive to infection. Losses caused by these diseases historically have been managed primarily by applying fungicides, although interest in integrated postharvest disease control has increased recently (Willett et al., 1989). Several biological and regulatory factors have spurred development of alternative disease management approaches. Development of resistance in pathogens to fungicides, particularly to benzimidazoles (Rosenberger and Mayer, 1979; Spotts and Cervantes, 1986), has limited or eliminated the effectiveness of these chemicals for postharvest use in some areas of the United States. Some countries that import fruit from the United States do not

Mention of a trade name, proprietary product, or specific equipment does not constitute a guarantee or warranty by the U.S. Dept. of Agriculture and does not imply its approval to the exclusion of other products that may be suitable. 'Supervisory Research Plant Pathologist. allow residues of some fungicides, such as $\mathrm{N}-[($ trichloromethyl)thio]4-cyclohexene- 1,2-dicarboximide (captan). Other countries, such as Japan, allow no residues of any postharvest fungicide on fruit imported from the United States. Additionally, emotional debates over chemical residues in food products (National Research Council, 1987), highlighted by the Alar (n-dimethylamino succinamic acid) controversy, have made some chemical companies reluctant to pursue re-registration of effective materials. Developing non- or reduced-chemical postharvest disease management strategies has become an economic imperative rather than an option.

Biological control of plant disease is not anew concept, but efforts to apply biological control theory to postharvest diseases of fruit are recent, as indicated by the scarcity of references to postharvest biocontrol in general texts and in reviews of biocontrol of plant pathogens (Baker and Cook, 1982; Cook and Baker, 1983; Lewis and Papavizas, 1991). Promising postharvest biocontrol agents have been identified, and significant efforts are being made to develop them for commercial use. Pioneering work by Tronsmo and Raa (1977) investigated the use of the filamentous fungus Trichodermapseudokoningii Rifai as an antagonist against gray mold (caused by B. cinerea) of strawberry (Fragaria $\times$ ananassa Duch.). Biocontrol yeasts, including Acremonium breve (Sukapure \& Thirumalachar) W. Gains (Janisiewicz, 1988), Candida guilliermondii (Castellani) Langeron \& Guerra [as Debaryomyces hansenii (Zopf) Lodder \& Krieger-van Rij] (Chalutz and Wilson, 1990; McLaughlin et al., 1990), Hanseniaspora uvarum (Niehaus) Shehata, Mrak \& Phaff (McLaughlin et al., 1989), Cryptococcus laurentii (Kuff.) C.E. Skinner, C. flavus (Saito) Phaff \& Fell, and C. albidus var. aerius (Saito) Phaff \& Fell (Roberts, 1990a, 1990b, 1991), are effective against various postharvest decays in several fruits 
and vegetables. Bacterial antagonists with postharvest biocontrol potential include, but are not limited to, Bacillus subtilis (Ehrenberg) Cohn (Pusey and Wilson, 1984), Pseudomonas cepacia Burkholder (Janisiewicz and Roitman, 1988; Janisiewicz et al., 1991), P. syringae pv. lachrymans (Smith and Bryan 1915) Young et al. (Janisiewicz and Marchi, 1990), Enterobacter aerogenes (Kruse 1896) Hormaeche and Edwards 1960 (Utkhede and Sholberg, 1986), and E. cloacae (Jordan 1890) Hormaeche and Edwards 1960 (Wisniewski et al., 1989). This group of microorganisms reflects considerable physiological and ecological diversity, yet to be successful postharvest biocontrol agents, they all must confer control under more or less similar conditions. Wilson and Wisniewski ( 1989) have discussed some of the characteristics necessary for successful postharvest biocontrol agents; many of these characteristics relate directly or indirectly to their compatibility with the postharvest environment. The remainder of this paper details 1) the conditions that exist in the modem postharvest environment, using the fruit industry as an example; 2) how some of the abovementioned antagonists fit into this environment; and 3) what can be done to facilitate and enhance biocontrol success within this environment.

The postharvest life of fruit begins at harvest, when the first of many possible wounds are formed at the stem end. Fruit is placed into picking bags or buckets that vary in cleanliness, and then are dumped into large wooden or plastic bins. Fruit can be bruised by the force of its own weight as it falls into these bins, wounded by stem puncture from other fruit, or abraded by the bin. The bins rest in contact with soil, which often is carried away on the bin skids, and then falls into the fruit-filled bins when they are stacked for transport to the packinghouse.

Once the fruit arrives at the packing/storage facility, the chronology of subsequent events varies, but exposure to recirculating water systems at least once and to various hard surfaces (belts, rollers, cups, brush beds) is a consistent feature of modem postharvest fruit handling systems. After harvest, 'Delicious' apples are typically drenched in the bins with a benzimidazole fungicide and diphenylamine (DPA) before being placed into RA or CA storage. Pears may receive a similar drench of benzimidazole and ethoxyquin before storage; some cultivars are also hydrocooled. Although the storage duration of cherries (Prunus avium L.) is short, they are often hydrocooled to remove field heat before further handling. Because the water in these drenchers and hydrocoolers recirculates, pathogen spores carried in the soil on the bins or on the fruit can build up in the water as successive bins are passed through the system.

Storage conditions may vary, but RA storage generally occurs at or near 0C. Variations in atmospheric composition in CA storage occur, but $1.5 \% \mathrm{O}_{2}, 2.0 \% \mathrm{CO}_{2}$, and 0 to $2 \mathrm{C}$ generally is used within the apple industry. These storage conditions may change incoming years as new storage methods are developed for newer cultivars and for nonchemical control of some disorders. After a storage period of up to 12 months, fruit is removed from cold or CA storage, graded, sized, waxed, boxed, and shipped. Some larger packing operations will pre-size apples using a system with several water flumes, then return the fruit to cold storage until enough orders are received for fruit of that size to warrant packing.

Regardless of whether fruit is pre-sized, apples and pears enter the packing line by floating out of their storage bins into immersion dumpers. Fruit is carried from point to point with the water flow. After floating into the dumper, fruit is elevated onto a system of belts, cups, or brush beds, where decayed or misshapen fruit are removed by hand and some initial grading occurs. Fruit is then returned to another water flume system, which carries it to the sizer, where fruit are segregated into common flume systems according to weight and often color. These fruit are then returned to bins for subsequent storage or immediate packing. After returning fruit to the bins, they often are drenched with a fungicide.

In areas where hard-water deposits on fruit resemble pesticide residues and interfere with wax application, fruit is floated into a hot acetic acid bath to remove these deposits before waxing. The fruit is subsequently washed and rinsed with any number of acidic or neutral detergent washes on a rotating brush bed, dried under blown air, and then waxed with either a shellac or carnauba wax, which usually contains thiabendazole. Wax solvents are driven off by hot air a $\approx 60 \mathrm{C}$. After waxing, the fruit is again inspected for defects, graded, and packed into a variety of bags, boxes, or specialty packs. Packed fruit is then returned to cold storage until it is shipped.

The above description of postharvest storage and handling of deciduous tree fruit in the Pacific Northwest (PNW) is not intended to be definitive, nor does it describe every procedure or process that fruit might be subjected to during its postharvest life. It describes the general conditions under which biocontrol agents must be able to work if they are to succeed in a commercial setting.

Integrating postharvest biocontrol into modem production, storage, and handling systems must begin before harvest. Preharvest factors that affect fruit quality, such as mineral nutrition and maturity at harvest, are important elements in sound fruit production practices that also have profound effects on the efficacy of postharvest biological control agents. Cultural controls and orchard sanitation practices also can incrementally increase the effectiveness of biocontrol systems.

Calcium sprays during the growing season can increase fruit firmness and decrease the incidence of certain disorders such as bitter pit (Raese et al., 1989). Conway and Sams (1983), working with apples, reported increased resistance to postharvest decay caused by $P$. expansum with calcium chloride applied by immersion infiltration at postharvest. Field applications of calcium chloride also can increase resistance in apple fruit to postharvest infection by $B$. cinerea (Roberts and Raese, 1990). Sugar et al. (1990) reported that the incidence and lesion size of blue mold and side rot [caused by Phialophora malorum (M.N. Kidd \& A. Beaumont) McColloch] of 'Bose' pears were reduced by minimizing fruit $\mathrm{N}$ and maximizing fruit $\mathrm{Ca}$ contents, and by postharvest $C$. laurentii application. They reported that $\mathrm{Ca}$ amendments and postharvest yeast application were additive in reducing fruit decay. McLaughlin et al. (1990) reported that applying the biocontrol yeast Candida guilliermondii in 2\% calcium chloride significantly increased disease control compared to applying the yeast or calcium chloride alone. The advantages of increased firmness, enhanced resistance to postharvest decay, and enhanced biocontrol efficacy under some circumstances reflect the multiple benefits of integrating postharvest biological control with cultural and production practices.

Another factor that will have major impact on the effectiveness of postharvest biological control is fruit maturity at the time of picking and at the application of antagonists. Late-picked, over-mature fruit are more susceptible to decay than are fruit picked at optimal storage maturity (Boonyakiat et al., 1987; Sommer, 1982). Maturity markedly affects biocontrol efficacy of C.laurentii, C. flavus, and C. albidus var. aerius against mucor rot of 'd' Anjou' pears (Roberts, 1990b). Coinoculating wounds on freshly harvested pears with sporangiospores of Mucor piriformis and vegetative cells of one of three Cryptococcus species gave excellent control of mucor rot. However, similar treatments of ripened pears resulted in much lower levels of biocontrol than in nonripened fruit, although the percentages of fruit infection were still significantly less than in the inoculated control fruit. A similar effect of maturity on biocontrol efficacy also has been observed with 'Golden Delicious' apple fruit (Roberts, unpublished). Through this work, I found that biocontrol of postharvest decay is maximized when the biocontrol agents are applied to the fruit as soon after harvest as possible. It is essential that fruit be picked at optimal maturity for longterm storage if biocontrol is to be optimized. Even when treated with biocontrol agents immediately after harvest, over-mature, late-picked fruit will be at greater risk of postharvest decay than fruit picked at optimal maturity.

Jarvis (1994) and Conway et al. (1994) addressed the subject of latent infections at this colloquium. The climate in the PNW during the growing season is normally hot and dry, and latent infections of apple and pear fruit by either $B$. cinerea or $P$. expansum are not significant problems to the fruit industry, although the same is not true for other fruit-producing regions of the world (Sommer et al., 1985). Climatic conditions in the PNW during the early growing season can, however, be conducive to episodic latent infections of apple and pear fruit by Cryptosporiopsis malicorticis, whose symptoms develop during and after storage. Wilson and Wisniewski (1989) suggested that biocontrol of latent infections may require antagonists or their products that 
penetrate the host. Bacillus subtilis (Gueldner et al., 1988; Pusey and Wilson, 1984) and Pseudomonas cepacia (Janisiewicz and Roitman, 1988; Janisiewicz et al., 1991) are among several known bacterial antagonists that produce extracellular antibiotics that may prove useful in treating latent infections. There is, however, no experimental evidence to support this suggestion. Another approach, requiring a sufficient understanding of microbial ecology and the biology of hostpathogen relationships, would be to apply biocontrol agents to the plant before the fungi that cause latent infections can become established in the host. Williamson and Fokkema's (1985) studies, for example, demonstrated that appressorium formation, which is usually an obligate event during penetration of grass leaves by Colletotrichum graminicola (Ces.) G.W. Wells, was significantly inhibited by phylloplane yeast application.

Just as preharvest factors can affect the effectiveness of abiologicrd control program, postharvest factors can be critical to the success of postharvest biological control. The degree to which the physiological and ecological characteristics of biological control agents are compatible with these factors, and our ability to provide the biocontrol agents with suitable conditions under which to work, will determine the ultimate success or failure of postharvest biological control strategies.

Temperature management is critical to successful maintenance of fruit quality during RA or CA fruit storage (Sommer, 1982) and for enhancing biological control of postharvest decay. Several studies (Janisiewicz et al., 1991; Roberts, 1990a) have demonstrated that as storage temperature decreases, the efficacy of biological disease control increases. A linear relationship was observed between the percentage of apple fruit that developed gray mold during storage and the storage temperature for $C$. laurentii- treated fruit and nontreated, inoculated controls (Roberts, 1990a). Mucor rot of pear was significantly reduced when wounded fruit were treated with several Cryptococcus species and then stored at 15,10 , or 5C, but disease development was less the lower the incubation temperatures for all treatments (Roberts, 1990b). A lower concentration of pyrrolnitrin, a metabolize of Pseudomonas cepacia and other Pseudomonas species, was needed at $2 \mathrm{C}$ than at $24 \mathrm{C}$ to protect apple and pear fruit from gray mold and blue mold (Janisiewicz et al., 1991). Assuming that the infection process can begin any time after harvest, it will be advantageous to treat fruit with biocontrol agents as quickly after harvest as possible, and to cool the fruit as rapidly as possible to retard pathogen development (Sommer, 1982). Slowing pathogen development while allowing microbial antagonists to colonize wound sites will be necessary if we are to maximize the benefits of biocontrol. One possibility would be to hydrocool (without chlorine) fruit after harvest with suspensions of appropriate biocontrol agents before placing them in storage. Another approach would be to drench fruit in bins as is done normally, then quickly fill storage rooms to prevent extended periods between harvest and attainment of storage temperature.

Once in storage, biocontrol agents must be able to colonize and protect fruit under cold and modified-atmosphere conditions. Levels of biocontrol achieved under various storage conditions are directly related to the concentration of the biocontrol agent applied to the wound (Chalutz and Wilson, 1990; Janisiewicz, 1988; Roberts, 1990a). Cryptococcus laurentii and C. flavus colonized apple (Roberts, 1990a) and pear (Shefelbine and Roberts, 1990) wounds under RA (1-5C) and $\mathrm{CA}\left(1.5 \% \mathrm{O}_{2}, 2 \% \mathrm{CO}_{2}, 1-2 \mathrm{C}\right)$ conditions, and in subsequent tests, controlled several diseases under these conditions (Roberts, unpublished). Janisiewicz and Marchi (1990) reported that Pseudomonas syringae pv. lachrymans colonized and persisted in pear fruit wounds when stored at $1 \mathrm{C}$ for 30 days, and apparently conferred some level of control of blue mold and gray mold during this period. The ability of a microbial antagonist to colonize wounded tissues in cold and reduced- $\mathrm{O}_{2}$ atmospheres could be an important characteristic when fruit are harvested, treated, and rapidly placed into CA storage. Assuming that storage conditions can be manipulated to retard pathogen development, the ability of antagonists to actively colonize wounds would increase the probability that wounds would be protected even by applying suboptimal concentrations of antagonists.

Perhaps the ultimate determinant of postharvest biological control success will be planning and implementing a thorough sanitation program that reduces pathogen contamination in all water systems and on hard surfaces that come in contact with fruit. Postharvest biological control agents are much more sensitive to the effects of pathogen concentration than are synthetic fungicides. Using different antagonist/pathogen systems, Chalutz and Wilson (1990), Janisiewicz (1988), and Janisiewicz and Roitman (1988) have demonstrated that when pathogen spore concentrations increase, biocontrol efficacy decreases. A similar result was obtained when wounded 'Golden Delicious' apple fruit were treated with varying concentrations of $C$. laurentii cells, challenged with conidia of $P$. expansum in increasing concentrations, and then stored at $15 \mathrm{C}$ for 7 days. Higher concentrations of $\boldsymbol{P}$. expansum resulted in increased infection percentages, regardless of the yeast concentration (Fig. 1) (Roberts, unpublished). For postharvest biocontrol to be successful, it must be integrated with a rigorous packinghouse sanitation program to reduce fruit exposure to pathogen spores. Build-up of inoculum originating in the orchard can be minimized by good bin sanitation before harvest and by minimizing the amount of soil adhering to bin skids during harvest (Michailides and Spotts, 1986). "Proper chlorine management in immersion dumpers and flume systems is critical in packinghouses to prevent inoculation of fruit as it is processed (Willett et al., 1989). The use of lignin sulfonate flotation salts in immersion dumpers on pear lines precludes the use of chlorine, but other materials such as orthophenylphenate (OPP) can be used instead of chlorine. Belts, rollers, cups, and brush beds can abrade fruit and, if contaminated with pathogen spores, can inoculate fruit. These hard surfaces must be cleaned routinely and treated with a hard-surface sanitizer, such as one of the quaternary ammonium compounds or chlorine dioxide foam. Some of the possible benefits of using aqueous chlorine dioxide in the postharvest environment have been reported previously (Spotts, 1980; Roberts, 1989). In recent tests to evaluate the effectiveness of chlorine dioxide foam in reducing surface contamination, several belt systems, pads, and the floor were sampled in a replicated design before and after applying a foam containing chlorine dioxide at $14 \mu \mathrm{g} \cdot \mathrm{ml}^{-1}$. Recovery of filamentous fungi from all surfaces was reduced greatly after foam treatment, with the greatest reductions occurring on those surfaces that were the most contaminated before treatment (Fig. 2) (Roberts, unpublished). Because biocontrol efficacy is so directly affected by the amount of pathogen inoculum present, successfully implementing packinghouse sanitation programs will be essential to applying biocontrol technology commercially.

Compatibility with fungicides, antioxidants, and other chemicals used during production and postharvest handling of fruit will be another factor that may determine the commercial suitability of postharvest biocontrol agents. Pusey et al. (1986) reported the compatibility of Bacillus subtilis with several types of waxes, 2,6-dichloro-2nitroaniline (dichloran), and simulated cold-storage conditions. A possible solution to poor biocontrol on mature fruit might be to formulate and apply biocontrol agents with greatly reduced concentrations of effective fungicides. Chalutz and Wilson (1990) showed that

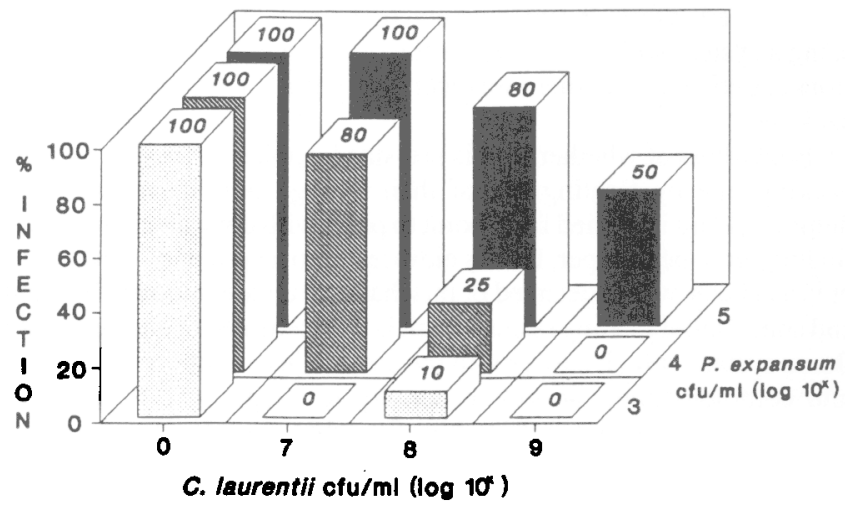

Fig. 1. Effects of pathogen and biocontrol yeast concentrations on biocontrol efficacy. 'Golden Delicious' apple fruit were wounded and treated with 0 , $10^{7}, 10^{8}$, or $10^{9}$ colony-forming units of C. laurentii cells per milliliter, then challenged with $0,10^{3}, 10^{4}$, or $10^{5}$ corridia of $P$. expansum per milliliter in a factorial design. Percentage of wounds that became infected were evaluated after 7 days at 20C. 


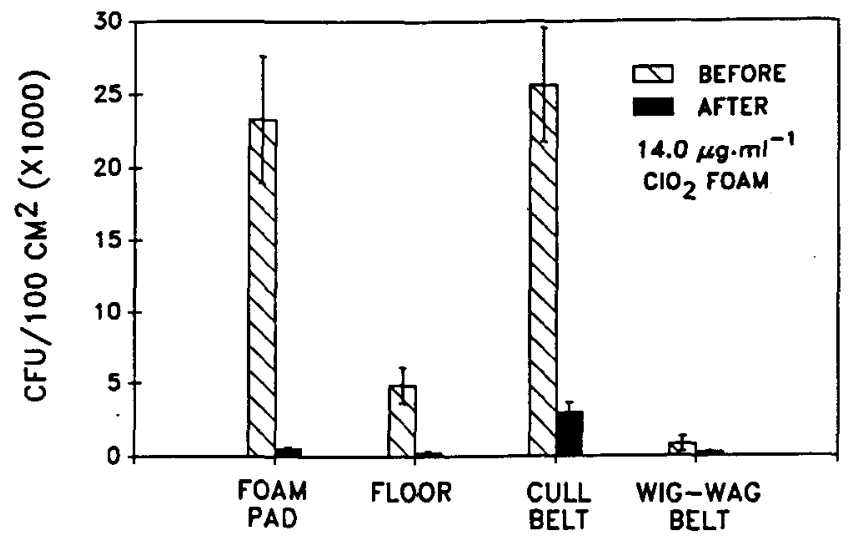

Fig. 2. Effect of chlorine dioxide foam on recovery of filamentous fungi (colony-forming units) from environmental surfaces in a packinghouse. Four areas $\left(100 \mathrm{~cm}^{2}\right.$ each) were sampled on each of four environmental surfaces by swabbing the surfaces with cotton and sterile distilled water, dilution-plating the water, then counting the resulting colonies. Foam pads, floor areas, a cull belt, and a wig-wag belt (waxer) were sampled before and after applying chlorine dioxide foam at $14 \mu \mathrm{g} \cdot \mathrm{ml}^{-1}$. Bars $=95 \%$ confidence interval.

Candida guilliermondii reduced the incidence of postharvest decay of citrus fruit when combined with 2-(4-thiazolyl)benzimidazole (thiabendazole) at $50 \mu \mathrm{g} \cdot \mathrm{ml}^{-1}$ and wax. In vitro filter paper disk tests have demonstrated that $C$. laurentii growth was not affected by postharvest label rates of the fungicides benomyl, thiabendazole, sodium orthophenylphenate, iprodione, or by the antioxidant diphenylamine (Roberts, unpublished). Captan slightly inhibited all strains of Cryptococcus tested. Both reducing postharvest fungicide residues and enhancing biocontrol may be realized with this approach.

Reducing inoculum loads in water systems and on hard surfaces, good temperature management after harvest and during storage, compatibility of biocontrol agents with fungicides, antioxidants, and CA storage all are important determinants of biocontrol agent performance. If all means were employed to reduce or eliminate sources of inoculum and increase host resistance, and if principles of good orchard management were uniformly practiced, then the risk of postharvest decay and the need for biological control likely would approach nil. In a perfect world, this might be true, and if there were ways to continually monitor the effectiveness of sanitation programs, mineral nutrition programs, etc., then biocontrol might in fact be spurious. However, we must recognize that such monitoring systems currently do not exist, and agricultural commodities are of such value that the prophylactic application of fungicides, biological control agents, or both will always be cheap insurance against an unseen foe. The ultimate benefits of integrating biological control into postharvest disease control strategies will be two-fold. First, it will encourage the vigorous implementation of sound pre- and postharvest production and handling practices, about which we already know but are sometimes reluctant to apply. Second, the use of environmentally safe and biologically sound technologies for controlling postharvest losses due to decay will become a realistic choice for postharvest disease management.

\section{Literature Cited}

Baker, K.F. and R.J. Cook, 1982. Biological control of plant pathogens. Amer. Phytopathol. Soc., St. Paul, Minn.

Baker, K.F. and F.D. Heald, 1932. Some problems concerning blue mold in relation to cleaning and packing of apples. Phytopathology 22:879-898.

Boonyakiat, D., P.M. Chen, R.A. Spotts, and D.G. Richardson. 1987. Effect of harvest maturity on decay and post-harvest life of 'd'Anjou' pear. Scientia Hort. 31:131-139.

Chalutz, E. and C.L. Wilson. 1990. Biological control of postharvest diseases of fruits and vegetables through manipulation of epiphytic plant microflora, p. 255-266, In: D.D. Bills and S. Kung (eds.). Biotechnology and food safety. Butterworth-Heinemarm, Boston.

Conway, W.S. and C.E. Sams. 1983. Calcium infiltration of Golden Delicious apples and its effect on decay. Phytopathology 73:1068-1071.
Conway, W.S., C.E. Sams, and A. Kelman. 1994, Enhancing the natural resistance of plant tissues to postharvest diseases through calcium applications. HortScience 29:751-754.

Cook, R.J. and K.F. Baker. 1983. The nature and practice of biological control of plant pathogens. Amer. Phytopathol. Soc., St. Paul, Minn.

Gueldner, C.G., C.C. Reilly, P.L. Pusey, C.E. Costello, R.F. Arrendale, R.H. Cox, D.S. Himmelsbach, F.G. Crumley, and H.G. Cutler. 1988. Isolation and identification of iturins as antifungal peptides in biological control of peach brown rot with Bacillus subtilis. J. Agr. Food Chem. 36:366-370.

Heald, F.D. and G.D. Ruehle. 1931. The rots of Washington apples in cold storage, State College of Washington Agr. Expt. Sta. Bul. 253.

Janisiewicz, W.J. 1988. Biocontrol of postharvest diseases of apples with antagonist mixtures. Phytopathology 78:194-198.

Janisiewicz, W.J. and A. Marchi. 1990. Biocontrol of blue and gray mold and survival of biocontrol agent on various pear cultivars in storage. Phytopathology 80:671.

Janisiewicz, W.J. and J. Roitman. 1988. Biological control of blue mold and gray mold on apple and pear with Pseudomonas cepacia. Phytopathology 78:1697-1700.

Janisiewicz, W., L. Yourman, J. Roitman, and N. Mahoney. 1991. Postharvest control of blue mold and gray mold of apples and pears by dip treatment with pyrrolnitrin, a metabolize of Pseudomonas cepacia. Plant Dis. 75:490494.

Jarvis, W.R. 1994, Latent infections in the pre- and postharvest environment. HortScience 29:749-751.

Lewis, J.A. and G.C. Papavizas. 1991. Biocontrol of plant diseases: The approach for tomorrow. Crop protection 10:95-105.

McLaughlin, R. J., M.E. Wisniewski, C.L. Wilson, and E. Chalutz. 1989. Biocontrol of postharvest rots of peach and apple with the yeasts Hanseniaspora uvarum and Debaryomyces hansenii. Phytopathology 79:1187.

McLaughlin, R.J., ME. Wisniewski, C.L. Wilson, and E. Chalutz. 1990. Effect of inoculum concentration and salt solutions on biological control of postharvest diseases of apple with Candida sp. Phytopathology 80:456461 ,

Michailides, T.J. and R.A. Spotts. 1986. Factors affecting dispersal of Mucor piriformis in pear orchards and into the packinghouse, Plant Dis. 70:106\& 1063.

National Research Council. 1987, Regulating pesticides in foods-TheDelaney paradox. Board of Agr., Natl. Res. Council. National Academy Press, Washington, D.C.

Pusey, P.L. and C.L. Wilson. 1984. Postharvest biological control of stone fruit brown rot by Bacillus subtilis. Plant Dis. 68:753-756.

Pusey, P. L., C.L. Wilson, M.W. Hotchkiss, and J.D. Franklin. 1986. Compatibility of Bacillus subtilis for postharvest control of peach brown rot with commercial fruit waxes, dichloran, and cold storage conditions. Plant Dis. 70:587-590.

Raese, J. T., S.R. Drake, and R.G. Roberts. 1989. Preharvest calcium treatments reduce storage disorders and improve fruit quality of apples and pears, $\mathrm{p}$. 53-61, In: Proc. 5th Intl. Controlled Atmosphere Res. Conf., Wenatchee, Wash., 14-16 June 1989.

Roberts, R.G. 1989, The potential for use of chlorine dioxide as a postharvest tool for the Pacific Northwest fruit industry, p. 37-40. In: Proc. 5th Annu. Warehouse Seminar and Trade Show, Wenatchee, Wash., 28-29 Mar. 1989. Wash. State Hort. Assn., Wenatchee.

Roberts, R.G. 1990a. Biological control of gray mold of apple by Cryptococcus laurentii, Phytopathology 80:526-530.

Roberts, R.G. 1990b. Biological control of mucor rot of pear by Cryptococcus laurentii, C. flavus, and C. albidus. Phytopathology 80:1051.

Roberts, R.G. 1991. Characterization of postharvest biological control of deciduous fruit diseases by Cryptococcus spp., p. 37-48 In: Biological control of postharvest diseases of fruits and vegetables. Wkshp. Proc. ARS92, U.S. Dept. Agr., Agr. Res. Serv.

Roberts, R.G. and J.T. Raese. 1990. Effect of apple fruit tissue calcium on postharvest biocontrol efficacy of Cryptococcus laurentii against Botrytis cinerea. Phytopathology 80:1050-1051.

Rosenberger, D.A. and F.W. Meyer, 1979. Benomyl-tolerant Petricillium expansum in apple packinghouses in eastern New York. Plant Dis. Rpt. 63:37-40.

Shefelbine, P.A. and R.G. Roberts. 1990. Population dynamics of Cryptococcus laurentii in wounds in apple and pear fruit stored under ambient or controlled atmospheric conditions. Phytopathology 80:1020.

Sommer, N.F. 1982. Postharvest handling practices and postharvest diseases of fruit. Plant Dis, 66:357-364.

Sommer, N.F., J.R, Buchanan, and R.J. Fortlage. 1985. Relation of floral infection to Botrytis blossom-end rot of pears in storage. Plant Dis. 69:340343.

Spotts, R.A, 1980. Chlorine and chlorine dioxide for control of 'd'Anjou' pear decay. Plant Dis. 64:1095-1097. 
Spotts, R.A. and L.A. Cervantes, 1986, Populations, pathogenicity, and benomyl resistance of Botrytis spp., Penicillium spp., and Mucor piriformis in packinghouses. Plant Dis. 70:106-108.

Sugar, D., R.G. Roberts, R.J. Hilton, E.E. Sanchez, and T.L. Righetti. 1990. Effects of fruit nutrient management and postharvest yeast application on fungat decay in pear, Phytopathology 81:1163,

Tronsmo, A. and J. Raa. 1977. Antagonistic action of Trichoderma pseudokoningii against the apple pathogen Botrytis cinerea. Phytopathol, Z. 89:216-220.

Utkhede, R.S. and P.L. Sholberg. 1986. In vitro inhibition of plant pathogens by Bacillus subtilis and Enterobacter aerogenes and in vivo control of two postharvest cherry diseases. Can. J. Microbiol, 32:963-967.
Willett, M., E. Kupferman, R. Roberts, R. Spotts, D. Sugar, G. Apel, H. Ewart, and B. Bryant. 1989. Integrated management of postharvest diseases and disorders of apples, pears, and cherries. Postharvest Pomol. Nwsl. 7:1-14. Washington State Univ. Ext. Serv., Pullman,

Williamson, M.A. and N.J. Fokkema. 1985. Phyllosphere yeasts antagonize penetration from appressoria and subsequent infection of maize leaves by Colletotrichum graminicola. Neth. J. Plant Pathol. 91:265-276.

Wilson, C.L. and M.E. Wisniewski, 1989 Biological control of postharvest diseases of fruits and vegetables: An emerging technology. Annu. Rev. Phytopathol. 27:425-441.

Wisniewski, M., C. Wilson, and W. Hershberger. 1989. Characterization of inhibition of Rhizopus stolonifer germination and growth by Enterobacter cloacae. Can. J. Bet. 67:2317-2323.

\title{
Genetic Manipulation of Plants to Improve Postharvest Disease Resistance
}

\author{
Mark S. Mount and Phyllis M. Berman \\ Department of Plant Pathology, Fernald Hall, University of Massachusetts, Amherst, MA 01003
}

We "mature" plant scientists over the age of $\mathbf{3 5}$ have had the pleasure of watching science fiction turn into science fact over the years. We have gone from slide rules to computers and from biology at the microscopic level to biology at the molecular level. We have not only learned from the mistakes of the past, we are the ones that made them. Our experience has taught us to be cautious and ecologically aware. However, at the same time, we understand that few things in science are impossible, and that innovations, even some seemingly bizarre, must be tried for progress to occur. Ten years ago, we might have laughed at the scientists who theorized that they could actually blast DNA into plants by shooting them with a "gene gun." Today, their success is part of this contribution.

After a brief introduction, describing what transgenic plants are and why the technology is important, this contribution will be divided into two sections. The first, which we call "State-of-the-Art," briefly summarizes some of the current technology involved in genetic engineering of plants. In the second section, "Designing the Future," we will speculate on possible avenues that transgenic plant research might take regarding postharvest disease management.

\section{What is a transgenic plant?}

A transgenic plant contains foreign DNA within its genome. The exogenous DNA, which was introduced artificially via genetic engineering techniques, must be able to be passed on through the plant's germline. This implies actual incorporation of the foreign DNA into the plant's nuclear material. However, we will also use the term "transgenic" to imply any stably inherited foreign genetic material in plants, whether the exogenous DNA has integrated into the nuclear genome or not. One example of the latter might be a plant infected with an altered DNA virus, which remains independent of the plant's nuclear material. However, the foreign gene will be expressed. It is also possible to genetically engineer a plant, even if no foreign DNA is involved. For example, a plant might be artificially manipulated to produce, over-produce, or not produce one of its own proteins by specifically mutating the gene's endogenous control mechanisms. Such a bioengineered plant technically may not be "transgenic," but the end result is an inheritably altered germline. For the purpose of this article, we will not specifically distinguish bioengineered, genetically engineered, or transgenic.

\section{Why create disease-resistant transgenic plants?}

Very simply, creating plant cultivars with inheritable genes for disease resistance is ultimately the most environmentally sound strategy for disease management (Mount and Berman, 1988). Reducing the amount of chemicals applied to crops for disease control certainly makes economic sense too. Altering the genetic make-up of plants for desired traits such as improved yield, increased size, hardiness, disease resistance, etc., is certainly not a new concept. Classical breeding has always provided, and continues to provide, new plant varieties having desirable characteristics. Even though advances in plant tissue culture techniques have certainly helped the science of plant breeding, the process can be too slow, and too inexact. Often, pathogens can mutate too quickly for classical breeding of disease-resistant plant varieties. Bioengineering offers a better shot at keeping one step ahead of the pathogens. New plant varieties with greater disease resistance could be developed more rapidly than via classical methods. Also, it maybe possible to simultaneously add multiple, diverse resistance genes to one plant variety. In addition, transgenic plant technology allows for a wider genetic diversity. Only through bioengineenng could beneficial genes from bacteria, fungi, viruses, or different species of plants be introduced into a plant's germline. But, and this is a very crucial "but," it is important not to rely on only one method of disease control for any particular plant crop. Transgenic plants should be viewed as one component of an "integrated" disease control strategy. This is especially true for postharvest diseases, to be detailed later.

\section{STATE-OF - THE - ART}

\section{Transformation methodology}

Although some transgenic plants with desirable traits and immediate marketable value have been successfully constructed (Council on Scientific Affairs, 199 1; Gasser and Fraley, 1989; Grierson and Covey, 1988; Miki et al., 1990; Old and Primrose, 1989), methodologies are still only in the "toddler" stages, and thus are still far from mature. In the long run, when the techniques are perfected, creating transgenic varieties from almost any plant species will be a "cookbook" routine. For now, at this early trial-and-error stage of experimentation, many problems still must be overcome, and several factors must be taken into consideration when designing a plant genetic engineering scheme. Luckily, with each new advancement in molecular biology techniques, the methodology for bioengineenng plants seems to take a quantum leap.

To construct a transgenic plant, a suitable cell line (whole plant, intact tissue, cultured cells, etc.) to receive the exogenous nucleic acid should be determined, then a methodology for DNA transfer can be chosen. Currently, there are several techniques being attempted, with various degrees of success. Again, there is no consistent, universal procedure that can be applied to all plant species.

Plant cell recipients. Knowing the limitations of the target plant species is very important when choosing a recipient cell line. Is it a dicot or monocot? Can the plant be propagated vegetatively? If the 